\title{
MICROFINANCE INSTITUTIONS AND SOCIAL EMPOWERMENT IN PALASTINIAN REFUGEES CAMPS IN JORDAN (AL-BAQA'A CAMP AS A MODEL)
}

\author{
AREEJ MOFEED DERBAS \& PROF. DR. MUHAMMAD FAYEZ AL-TARAWNEH
}

University of Jordan, Amman-Jordan

\begin{abstract}
The research aims to examine the role of microfinances institutions in the Palestinian refugee camps in Jordan. The study adopted the qualitative approach. The study sample comprised of beneficiaries from the MFI's in Al Baqa'a Refugee Camp, who received loans from the MFI's in 2008-2018 was taken using the snowball sample of the research population. The sample comprised of 113 male and female respondents broken down as follows: 20 respondents who participated in the indepth personal interviews and 93 respondents who participated in the focus group discussions (18 FGDs). The results show that the majority of benefits are females comparing with males with a high school certificate or less. And they are unemployed with small amount incomes. The household size of 80 percent of the respondents was 4-8 members. According to the respondents, the majority of enterprises were related to purchasing vehicles to commute students, transport vegetables and fruits, or sell detergents; establish hairdressing or selling from home. The respondents pointed to the role of small enterprises in developing their social empowerment, enhancing their household relationships, having strong social relationships, increasing their self-confidence, developing the quality of life and communication with the surrounding community, and increasing household awareness of the importance of engaging all household members in the decisionmaking process. Moreover, the majority of respondents confirmed that their participation in small enterprises made them "more compliant with the laws and instructions in their communities. The respondents confirmed that the small enterprises had helped improve their quality of life in terms of better level and quality of social relationships, able to communicate with the surrounding persons and participate in the different social events as they have become able to cover the cost of such events. This emphasizes the role of such enterprises in enhancing social empowerment at the beneficiary level on the one hand, and household level and household relationships on the other, along with their community relationships.

KEYWORDS: Enterprises, Social Empowerment, Surrounding Community
\end{abstract}

Received: Sep 26, 2020; Accepted: Oct 16, 2020; Published: Nov 10, 2020; Paper Id.: IJAFMRDEC20202

\section{INTRODUCTION}

Microfinance Institutions (MFIs) represent a significant element role in socio-economic development, as they play a major role in the economies in terms of maintaining economic balance, which, in turn, improves social protection through creating many job opportunities and generating income for a large number of households and individuals. In spite of the critical role of small enterprises in the economy as they represent over 90 percent of the establishments in most countries around the world, they still face some obstacles against their development. In Jordan, small enterprises require more support through financing, Commercial banks, non-banking public agricultural credit institutions, and credit companies in Jordan are the main supporters of such enterprises. (Al Mahrouq, Maqableh, 2006) According to the population and housing census conducted by the Department of Statistics 
(DOS) in 2018, the total population in Jordan reached 10,309,000, of them over 2.1 million are Palestinian refugees. A round 410,000 of these refugees live in 10 official camps and 3 other unofficial camps. (DOS, 2018)

\subsection{Research Problem}

Small enterprises face a number of obstacles that limit their desired role. This can be attributed to reasons related to the credit institutions or the target group itself. To this end, this research aims to examine the role of MFIs from the perspective of beneficiaries in the Palestinian refugee camps in Jordan with regards to social empowerment. This will be done through answering the following question: :

\section{1- How can MFIs support social empowerment in the Palestinian refugee camps in Jordan?}

\subsection{Research objectives:}

This research aims to examine the role of MFIs in social empowerment in the Palestinian refugee camps in Jordan through addressing the following objective :

1- Understand the role of MFIs in social empowerment in the Palestinian refugee camps in Jordan.

\subsection{Research Significance}

Small enterprises are of great importance due to their big role in increasing production and creating job opportunities. This research is important as it tries to find out about the role of the small enterprises financed by the MFIs in social empowerment in the Palestinian refugee camps in Jordan.

\subsubsection{Practical Significance}

This research is practically significant as it is one of the research that address the role of the small enterprises financed by the MFIs in providing opportunities of social empowerment in the Palestinian refugee camps in Jordan.

\subsubsection{Theoretical Significance}

This research has theoretical significance as it aims to find out how small enterprises financed by the MFIs can help enhance social empowerment and provide information and data that enable development actors to develop their procedures and better serve individuals in the field of social empowerment.

\subsection{Theoretical Framework used in the Research}

Marc A. Zimmerman considered empowerment to be both a value orientation for working in the community and a theoretical model for understanding the process and consequences of efforts to exert control and influence over decisions that affect one's life, organizational functioning and the quality of community life. Zimmerman defines empowerment as "looking at empowerment as a successful process through which individuals learn how to see and document alignment between their goals and the feeling of how to achieve them". (Zimmerman, 2012) According to Zimmerman, empowerment theory includes empowerment processes and their results that lead to a certain level of empowerment, provided that the actions can be empowerment, and the result of such processes leads to a certain level of empowerment. Empowerment processes and their results differ in their outputs and level of analysis: individual, institutional, and community levels. As for empowerment results and outputs, they refer to the operationalization of empowerment in order to consider and understand the efforts made the people to have the maximum possible control in their community. In addition, the empowered results differ by levels of analysis (Perkins, Zimmerman, 1995) 


\subsection{Previous Studies}

In his study entitled "The Youth and Income Generating Small enterprises" Khummash (2014) aimed to analyze the current situation of the male and female young people in Jordan, who started-up their own small enterprises , and the socioeconomic characteristics of these young people. This study came up with a number of conclusions, mainly: most small enterprises are female-owned, small enterprises help improve quality of their owners' life and increase respect and appreciation of those around them, and they help create sustainable job opportunities. (Khummash, 2014)

Entitled "The Role of Small enterprises in Reducing Poverty and Unemployment in Yemen: A Field Study in the Capital Municipality", Ghalib (2010) concluded that loaning is the main activity of microfinance programs, and small enterprises witnessed an increase in income of the beneficiary households. From a social perspective, the small enterprises had a positive impact on social empowerment, represented by reduced social problems caused by lack of income, improved health and educational outcomes for household members, enhanced social household relationships, and better fulfillment of household needs. (Ghalib, 2010)

The study of Abu Hajleh (2004), entitled “An Evaluation of Impact of Small/Microfinance Programs of Private Organizations on Improving Standards of Living of the Beneficiaries in Jordan: A Field Study", examined to what extent such programs had achieved their objectives and evaluated their impact on the beneficiaries. The study concluded that small enterprises had helped increase levels of income. In addition, the main social impacts of such programs included an increase of self-confidence, self-reliance, participation in household decision-making processes, and development of self capabilities. (Abu Hajleh, 2004) .

In 2002, Hattab's study, entitled "Impact of Credit Programs of UNRWA on Empowering Female BeneficiariesA Field Study", tried to examine the situation of the females who benefited from the credit programs to startup their own enterprises, and the impact of such enterprises on the household, self, and socio-economic situation of the female beneficiaries. The study tool was a questionnaire. The study concluded that the sample population felt with an increasing social value by those around them, and they had become more self-dependent in personal decision-making (Hattab, 2002).

\subsection{Theoretical Definitions}

2.3.1 Small Enterprises: Enterprises that are characterized by low capital, limited number of workforce, small sales, and limited operational capacity needed. They are also closely linked to the environment, depend on local raw materials, and market their products in the same area or its surroundings. (Jawad, 2007)

2.3.2 Empowerment: It refers to empowering the person to become a member of a group of community able to play certain roles. This takes place through social interaction processes, socialization activities, and social normalization (Al Shayab, Abu Hammour, 2014)

2.3.3 Social Empowerment: Provision of the basic human rights as a guarantee of a long and healthy life, descent standard of living, appropriate education, productive job opportunities without any gender discrimination, prevention of all forms of violence, and give the right to development to everyone. (Al Shayab, Abu Hammour, 2014)

\subsection{Procedural Definitions}

2.4.1 Small enterprise: The establishment, company, or factory that is managed, funded, controlled, and followed-up by their owners with a small number of workforce . 
2.4.2 Empowerment: Having the power to become an actively participant in all walks of socio-economic life, meaning the ability to make a change in the other, develop participatory self-capabilities, and enhance self-potentials and existence .

2.4.3 Social Empowerment: Social empowerment can be achieved through economic empowerment and increasing capabilities of the individuals or groups to make choices and turn them into the desired procedures and results.

\subsection{Study Methodology}

After making contacts with the competent persons in The United Nations Relief and Works Agency for Palestine Refugees in the Near East (UNRWA) in the area of field studies, it was agreed to examine the role of the MFIs and social empowerment in the Palestinian refugee camps in Jordan. In order to meet the study objectives and answer the related questions, the qualitative methodology was adopted using the following data collection tools:

- $\quad$-Focus group discussions of the MFI's beneficiaries

- $\quad$-Interviewing some beneficiaries of the MFI's..

\subsection{Data Collection Tools}

In order to obtain the research-related data, data was collected using the following tools :

- $\quad$-Interviewing guide of focus group discussions

- $\quad$-Interviewing guide of individuals .

\subsection{Research Population}

The total number of Palestinian refugees in the 13 refugee camps in Jordan is around 410,000 according to UNRWA statistics. The total population of Al Baqa'a Refugee Camp is around 122,579. The study population will include all beneficiaries from the MFI's in Al Baqa'a Refugee Camp in 2008-2018.

\subsection{Research Sample}

A sample of beneficiaries from the MFI's in Al Baqa'a Refugee Camp, who received loans from the MFI's in 2008-2018 was taken using the snowball sample of the research population. The sample comprised of 113 male and female respondents broken down as follows: 20 respondents who participated in the in-depth personal interviews and 93 respondents who participated in the focus group discussions (18 FGDs) at the rate of 5-6 respondent per FGD.

\subsection{Validity and Reliability of the Tool}

Validity and reliability of the tool was measured through the following procedures:

- $\quad$ Present the tool to 3 experts of scientific research

- $\quad$ Test the tool with 3 owners of small enterprises financed by the MFI's.

\section{FINDINGS}

\subsection{Analysis of Research Sample Data}

Data indicates that 73 percent of the respondents were females compared to 27 percent of male respondents. 60 percent of total respondents hold a high school certificate or less, 23 percent hold a diploma degree, and 12 percent hold a university 
degree. The percentage of working respondents was 44 percent compared to 51 percent as unemployed. Data also shows that the average monthly household income of 75 percent of the respondents ranges between JD 200-600, while 19 percent of the respondents confirmed that their monthly income is less than JD 200. The household size of 80 percent of the respondents was 4-8 members, while 17 percent of the respondents confirmed that their household size is more than eight members .

According to the respondents who participated in the focus group discussions, the majority of enterprises were related to purchasing vehicles to commute students, transport vegetables and fruits, or sell detergents; establish hairdressing or barbershops; cover household costs such as debt repayment or marriage costs. The enterprises of total respondents who participated in the focus group discussion were selling from home of blankets, clothing, and baby supplies), establishing sewing shops, selling detergents and spices, selling make-up products and cosmetics, or establishing a commercial cooking shops.

\subsection{Analysis of Data on the Role of MFI's in Social Empowerment of the Beneficiaries in the Palestinian Refugee Camps in Jordan}

The respondents confirmed that 65 percent of the small enterprises had helped improve their quality of life in terms of better level and quality of social relationships. As a result, the participating respondents have become able to communicate with the surrounding persons and participate in the different social events as they have become able to cover the cost of such events. All the respondents who participated in the personal interviews confirmed that the funding they had received through which they established their small enterprises had helped "increase their ability to make household decisions', "enhance their self-confidence and personality", and "expand their participation in all walks of social life". This emphasizes the role of such enterprises in enhancing social empowerment at the beneficiary level on the one hand, and household level and household relationships on the other, along with their community relationships. In addition, all respondents stressed that the enterprises "enhanced my household awareness of the importance of involving all members in the decision-making processes", "improved my household relationships", and "made my household happier and more coherent".

The respondents expressed their feelings by saying :

- "I was not able to communicate with my household members. However, after owning my enterprise through financing, I became more able to communicate with my household members and more thoughtful to the problems and needs of my children." A participant in the structured personal interviews .

- "I used to feel with low self-esteem in front of those around me. When I started-up my small enterprise, I became more able to express my opinion and participate in all surrounding activities, and increased by self-confidence and ability to make decisions." A participant in the structured personal interviews.

Furthermore, the respondents who participated in the focus group discussions pointed to the role of small enterprises in developing their social empowerment, enhancing their household relationships, having diversified and strong social relationships, increasing their self-confidence, developing the quality of life and communication with the surrounding community, and increasing household awareness of the importance of engaging all household members in the decision-making process. Moreover, the majority of respondents confirmed that their participation in small enterprises made them "more compliant with the laws and instructions in their communities", "enhanced their relationship with their 
communities", and increased their integration into the community. This stresses the importance of such enterprises in enhancing social solidarity in the community. Both respondents who participated in the personal interviews and focus group discussions agreed that the enterprises made them "more understandable of the conditions and needs of the others in their community ".

The respondents expressed their feelings by saying:

- $\quad$ Of course, my life improved because I bought a house and felt independent. Without the loan, I would not be been able to buy a house of myself and family and become separated from interference of my extended family." A female respondent who participated in the focus group discussions .

- $\quad$ "For me, I am so happy with my work. I have my own relationships and able to cover educational expenses of my children without the need of anyone." A female respondent who participated in the focus group discussions.

- $\quad$ The female respondents who participated in the focus group discussions stressed that their participation in small enterprises made them "more able to make different household decisions" and "my household is now more supportive psychologically and financially".

The respondents expressed their feelings by saying:

- $\quad$ "I did not expect to be self-content. I spend as I want and save for myself and children. What I am doing now was a dream for me. Even when we remember how our life was before I started-up my small enterprise, everything has changed, even my self-confidence and my children's confidence in themselves and me." A female respondent who participated in the focus group discussions .

- "Yes, it is a dream that came true. I wished to have an enterprise to make money to cover expenses of myself and my household." A male respondent who participated in the focus group discussions.

\section{RESEARCH RECOMMENDATIONS}

- Provide technical support along with the financial support from the MFI's to small enterprise owners .

- Reconsider the amount of loans provided by the MFI's and consider feasibility of such loans for the potential enterprises before making the final credit decisions .

- Focus local community trends towards women employment and small enterprises to gain community support and advocacy for such enterprises to ensure their sustainability .

- Enhance follow-up of the MFI's with the beneficiaries to ensure their ability to repay the debt.

- Reconsider the grace period given for the small enterprise borrowers to ensure their sustainability

\section{REFERENCES}

1. Abu Hajleh, Maher (2004). An Evaluation of Impact of Small/Microfinance Programs of Private Organizations on Improving Standards of Living of the Beneficiaries in Jordan: A Field Study. A Master thesis, University of Jordan, Amman, Jordan.

2. Jawad, Nabil (2007), Management and Development of SMEs. University Institution for Studies, Publication, and Distribution: Beirut . 
3. Hattab, Minan (2002), Impact of Credit Programs of UNRWA on Empowering Female Beneficiaries- A Social Field Study. Unpublished Master thesis, University of Jordan, Amman, Jordan .

4. Khammash, Majed Eddin, et al. (2014). Young People and Income-generating Enterprises, Individual Enterprises to Face Poverty and Unemployment. With support of the Scientific Research Support Fund-Ministry of Higher Education and Scientific Research, Amman, Deanship of Scientific Research, University of Jordan, Amman, Jordan .

5. Department of Statistics (2018). Population at the end of 2018, official website of DOS http://dosweb.dos.gov.jo/ar/population/population/

6. Al Shayab, Ahmed Mohammed, Abu Hammanal, Adnan Mohammed (2014). Contemporary Managerial Concepts. Dar Al Manhal: Amman.

7. Ghalib, Nabila Abdullah (2010). The Role of Small enterprises in Reducing Poverty and Unemployment in Yemen: A Field Study in the Capital Municipality. Unpublished doctoral dissertation. University of Jordan, Amman, Jordan.

8. Al Mahrouq, Maher and Maqableh, Ihab (2006). SMEs: Significance and Obstacles. SME Center: Amman, Jordan .

9. Zimmerman, Marc A, 2012, Empowerment Theory, Psychological Organizational, and Community Levels of Analysis, University of Michigan.

10. Perkins, Douglas D, Zimmerman, Marc A, 1995, Empowerment Theory, Research and Application, American Journal of Community Psychology, October 23, research library core, vol.23 No.5 

